\title{
The Effects of Business Strategy and Inventory on the Relationship between Sales Manipulation and Future Profitability
}

\author{
Hwa Deuk Yi ${ }^{1}$, Sambock Park ${ }^{2, *}$ and Jonghyun Kim ${ }^{2}$ \\ 1 School of Business, Hanyang University, 222 Wangsimni-ro, Seongdong-gu, Seoul 133-791, Korea; \\ hwayi@hanyang.ac.kr \\ 2 College of Business and Economics, Hanyang University ERICA, 55 Hanyangdaehak-ro, Sangnok-gu, \\ Ansan-si, Gyeonggi-do 15588, Korea; jhkim04@hanyang.ac.kr \\ * Correspondence: psp96@hanyang.ac.kr; Tel.: +82-10-3780-7745
}

Received: 1 March 2019; Accepted: 16 April 2019; Published: 22 April 2019

\begin{abstract}
Many researchers have found that real activities manipulation undermines future profitability, because it deviates from normal operating activities. We are interested in sales manipulation, which is one type of real activities manipulation relating to corporate sustainability. First, we empirically examine whether the effects of sales manipulation on future profitability differ according to the strategies of a firm. Next, we divide sales manipulation as a type of real activities manipulation and optimal sales manipulation and then examine how the two types of sales manipulation affect future profitability. Finally, we examine how the effects of optimal sales manipulation on future profitability differ according to the firm's strategies. The empirical findings show that the association between sales manipulation and future profitability is more negative (-) for a product differentiation strategy than for a cost leadership strategy. Further, the sales manipulation performed by firms with a high proportion of the starting inventory and a decrease in the inventory during the current year has a positive (+) impact on future profitability. Our results contribute to the literature on business strategy by presenting evidence that core management activities are related to future financial performance, according to the business strategy. In addition, our research shows that sales manipulation can turn into an optimal operating activity, depending on the firm's situation.
\end{abstract}

Keywords: sales manipulation; future profitability; business strategy; inventory

\section{Introduction}

Managers make necessary decisions, while adapting to the resources that they have and the environmental factors of a firm. They also increase the likelihood of long-term growth by optimally allocating their resources. In this regard, Hambrick (1983) [1] defines business strategy as a series of decision-making processes that combine and harmonize the threats and opportunities in a given environment with the available resources of the organization in order to gain a competitive advantage in the market. Namely, business strategy is an important factor for a firm's survival and growth.

Meanwhile, firm managers perform sales manipulation to meet or beat the expected performance because sales indicate a firm's growth. Sales manipulation refers to the behavior of managers that attempts to increase sales during the current year in an effort to increase reported earnings. For sales manipulation, firms can increase current sales and earnings through increased price discounts or more lenient credit conditions. However, this sales manipulation technique may have a negative (-) impact on future performance by damaging the brand value of the product and increasing future bad debt. Prior studies document that real activities manipulation (sales manipulation, over-production, decreasing discretionary expenses, etc.) can be more harmful to future profitability, because it deviates 
from normal operating activities (Gunny, 2010 [2]; Zang, 2012 [3]; Kim et al., 2009 [4]). Chun et al. (2012) [5] argue that mangers of Korean-listed firms have strong incentives to use real activities manipulation, rather than accrual-based earnings management. Therefore, we are interested in sales manipulation, which is one type of real activities manipulation relating to corporate sustainability.

First, we empirically examine whether the effects of sales manipulation on future profitability differ according to the strategies of a firm. Business strategy, a means of achieving corporate goals, is one of the most important decision-making processes and has a significant impact on the current and future financial status, as well as business performance. In general, there are two broad categories (cost leadership or product differentiation strategy) of business strategy (Porter, 1985 [6]). Porter's (1985) [6] classification of business strategy is academically accepted. Firms pursuing a cost leadership strategy want to exist as low-cost producers in the industry by emphasizing cost controls. They focus on the efficiency of production and sales as a strategy to maintain a very high level of sales by supplying goods at low prices (Porter, 1985 [6]). Firms pursuing a product differentiation strategy can maintain high prices, because they target a niche market and provide good quality and differentiated products, compared to their competitors. They also focus on developing new products through high-level research and development (R\&D) activities and dominating the market in advance. Therefore, the adverse effect of sales manipulation on future profitability is expected to be greater for the product differentiation strategy than for a cost leadership strategy, because the brand value is more damaged, and price recovery to normal is more difficult using a product differentiation strategy. When sales manipulation and a firm's core activities are more relevant, future profitability will further decrease.

Next, all types of sales manipulation, from price discounts to more lenient credit terms, may not have a negative (-) impact on future profitability. If the future expected loss due to sales through price discounts or more lenient credit terms is less than the expected loss due to an increase in inventory holding costs and inventory obsolescence, in this case, sales manipulation will have a positive (+) impact, not a negative (-) impact, on future profitability. In this regard, we define the sales manipulation performed by firms with a high proportion of the starting inventory and a decrease in the inventory during the current year as an optimal sales manipulation (an optimal operating activity). Optimal sales manipulation consists in reducing future expected losses due to an increase in inventory holding costs and inventory obsolescence. The accumulation of inventory assets means a sluggish demand and weakening of firm competitiveness, which negatively affects the firm value (Ou and Penman, 1989 [7]; Abarbanell and Bushee, 1997 [8]). Therefore, we divide sales manipulation, as a type of real activities manipulation and optimal sales manipulation, and then examine how the two types of sales manipulation affect future profitability.

In addition, considering the association between optimal sales manipulation and future profitability, in terms of strategy, firms pursuing a product differentiation strategy have a significant increase in inventory holding costs, when they do not engage in an optimal operating activity. They also experience a heavy loss due to obsolescence of inventory assets. In addition, given the frequent launch of new models and new products, firms that employ a product differentiation strategy are expected to have larger expected inventory losses, due to an increase in inventory holding costs and inventory obsolescence, than firms that employ a cost leadership strategy. Therefore, we examine how the effects of optimal sales manipulation on future profitability differ according to the firm's strategies.

The empirical results are summarized as follows. First, the results show that the association between sales manipulation and future profitability is more negative (-) for a product differentiation strategy than for a cost leadership strategy. This means that firms that employ a product differentiation strategy are more likely to damage their brand value due to sales manipulation because they supply expensive and differentiated products to the market. Second, the sales manipulation performed by firms, where the proportion of the starting inventory is high and ending inventory is reduced, has a positive (+) impact on future profitability. This suggests that sales manipulation can be used as a means of an optimal operating activity. Third, the results indicate that the association between an 
optimal sales manipulation and future profitability is more positive $(+)$ for product differentiation firms than for cost leadership firms.

The results of this study are expected to have some contribution to academic and practical research. First, our findings show that business strategy, which is an environmental factor of firms, should be considered when analyzing the effect of earnings management on future profitability and the future value of a company. Second, we contribute to the literature on business strategy by presenting evidence that core management activities are related to future financial performance, according to the business strategy. In other words, the finding that sales manipulation differentially affects future financial performance, according to the business strategy, is expected to help managers make decisions about sales manipulation. Third, our research shows that sales manipulation is an optimal operating activity in the case of an increase in inventory holding costs and inventory obsolescence.

The remainder of the paper is organized as follows. Section 2 reviews the related literature and develops the testable hypotheses. Section 3 discusses the research design. Section 4 presents the empirical results of the study. Finally, Section 5 concludes the study.

\section{Literature Review and Research Hypotheses}

\subsection{Business Strategy}

Hambrick (1983) [1] defines strategy as a series of decisions that combine and harmonize the threats and opportunities in a given environment with the available resources of the organization in order to gain a competitive advantage in the market. A representative study of strategy modeling is the business strategy model of Porter (1985) [6]. Porter (1985) [6] classified strategy into cost leadership and product differentiation strategies, with the concept of the product market area, strategic goal, and competition. A cost leadership strategy requires the aggressive construction of efficient-scale facilities, vigorous pursuit of cost reductions from experience, tight costs and overhead control, avoidance of marginal customer accounts, and cost minimization in areas, such as R\&D, service, sales force, advertising, etc. A product differentiation strategy requires competition by offering unique products in terms of quality, physical characteristics, or product-related services (Porter, 1985 [6]; Jermias, 2008 [9]).

Prior studies have shown that strategic orientation improves firm performance by selecting the appropriate direction of the firm's activity. For example, Day and Wensley (1988) [10] showed that based on Porter's strategy, firms can improve future performance when their resources and capabilities are strategically well-structured. Zahra (1996) [11] reported the results of a study that explored the differences in the technology strategies and performance of a firm and independent ventures. Kim and Han (2003) [12] classified firms' competition strategies for venture firms and identify the characteristics of the industrial structure, according to classification types. They also found that there is a difference in firm performance, depending on the type of venture strategy employed. O'Brien (2003) [13] found that business strategy and financial leverage interact significantly, affecting firm performance. Jermias (2008) [9] also found that business strategy affects the leverage-performance relationship, such that it is more negative (-) for product differentiation firms than for cost leadership firms.

Meanwhile, Selling and Stickney (1989) [14] investigated the behavior of the rate of return on assets (ROA) over time and across firms and industries. They reported that firms can pursue a higher ROA by increasing their profit margin via a product differentiation strategy or by increasing asset turnover via a cost leadership strategy. Yi et al. (2010) [15] showed that asset turnover and profit margin tend to be reversed. The empirical results showed that product differentiation firms show a decrease in profit margins and an increase in asset turnover, while cost leadership firms show an increase in profit margins and a decrease in asset turnover. The results also showed that an increase in profit margins and asset turnover for product differentiation firms is more closely related to future profitability improvements than cost leadership firms. Yi and Park (2014) [16] examined whether business strategy affects the association between $R \& D$ and future performance. The results showed that $R \& D$ has a greater impact on future performance for product differentiation firms than for cost 
leadership firms. The above results emphasize the need to consider moderating factors, such as strategic choice and the environment, when operating a firm.

\subsection{Earnings Management}

Earnings management occurs when managers use judgment in financial reporting and in structuring transactions to alter financial reports in order to either mislead some stakeholders about the underlying economic performance of the company or to influence contractual outcomes that depend on the reported accounting practices (Healy and Wahlen, 1999 [17]).

There are various incentives for a firm to engage in earnings management. According to these incentives, Schipper (1989) [18] classifies earnings management as either accrual-based earnings management or real activities manipulation. Accrual-based earnings management is a method of managing financial reports using accounting methods or accounting estimates, rather than by changing a firm's operational decisions. In contrast, real activities manipulation manages earnings upward by changing a firm's operational activities through, for instance, sales manipulation, the reduction of discretionary expenditures, and overproduction (Roychowdhury, 2006 [19]). Since Roychowdhury (2006) [19] proposed a measurement model of real activities manipulation, subsequent studies that use this model have been actively conducted.

Since accrual-based earnings management and real activities manipulation have their strengths and weaknesses, managers choose the appropriate earnings management tool, considering the circumstances. The main weakness of accrual-based earnings is that accruals are subject to supervision by the accountants of regulators. On the other hand, real activities manipulation is undermining future profitability, because it is a suboptimal operating activity that deviates from an optimal operating activity (Cohen and Zarowin, 2010 [20]; Zang, 2012 [3]).

According to a study by Gunny (2010) [2], managers make decisions, such as the reduction of discretionary expenditures, selective disposal of tangible assets, and increasing production, to report a lower cost of goods sold in order to manage upward earnings. However, these types of real activities manipulation have a negative (-) effect on the future performance of a firm. Kim et al. (2009) [4] also found that earnings management through real activities manipulation undermines future profitability. The reason for the deterioration of future profitability due to earnings management through real activities manipulation is that the expected loss from discount sales or lenient credit conditions is larger than the inventory holding costs when the inventory is not sold.

On the other hand, if the future expected loss due to sales through price discounts or lenient credit conditions is less than the expected loss due to an increase in inventory holding costs and inventory obsolescence, in this case, sales manipulation will have a positive (+) impact, not a negative (-) impact, on future profitability. In this case, earnings management through real activities manipulation is an optimal operating activity.

Meanwhile, earnings management may increase future profitability. This is because earnings management serves as a signaling effect for a firm's stakeholders. Burgstahler and Dichev (1997) [21] report that it is important for managers to report earnings in accordance with an analyst's earnings forecasts to build trust and reputation among investors. Bartov et al. (2002) [22] and Lev (2003) [23] argue that managers manage earnings to reduce litigation risk by giving credibility to investors and to meet/beat the analyst's earnings forecasts. This implies that earnings management can increase a firm's value. In addition, Gunny (2010) [2] finds that firms performing earnings management through real activities manipulation to meet/beat the analyst's earnings forecasts are more profitable than those that do not. These results are interpreted to mean that earnings management can be seen not as opportunistic behavior on the part of the manager, but rather as signaling a positive (+) future for investors. 


\subsection{Inventory}

Level changes in the inventory can provide two conflicting signals in relation to future operating performance. For example, if sales growth is anticipated, managers can increase inventory levels by accelerating production activities during the period, in which case inventory levels provide predictive information about the firm's future performance (White et al., 1994 [24]; Bernard and Stober, 1989 [25]; Jiambalvo et al., 1997 [26]). Likewise, if demand is expected to decline, inventory levels will be reduced in advance.

On the contrary, if the performance of the current period is not good, managers may increase the level of the inventory at the end of the year by increasing the production scale for the purpose of raising the reported earnings (Roychowdhury, 2006 [19]; Gupta et al., 2010 [27]). Overstating the ending inventory has the effect of lowering the cost of goods sold and raising the reporting earnings. In this case, overstating the ending inventory of the current period has a negative (-) impact on future performance.

White et al. (1994) [24] report that if sales are expected to increase in the future, managers can increase the level of ending inventory abnormally. Bernard and Noel (1991) [28] argue that the relationship between inventory changes and earnings is different for each stage of production due to the delivery of the inventory or manufacturing flexibility. They report that an abnormal increase of finished goods has little relevance for future sales and has negative relevance for future earnings, but an abnormal increase of raw materials and work in the process has a positive relationship with future earnings. In addition, Bernard and Stober (1989) [25] argue that, as the ending inventory increases beyond the expected level, not only do future sales increase, but the stock return of the current period is also affected. Kim (1993) [29] investigated the relationship between the level of unexpected inventories and future sales by dividing the interaction into eight stages, according to the holding period of inventory. The results show that there is a significant positive (+) relationship between the unexpected fluctuation of inventory and future sales in the mid-stage firms.

On the other hand, Ou (1990) [30] reports that the unexpected fluctuation of the inventory has a negative relationship with future net income. Abarbanell and Bushee (1997) [8] investigated whether future earnings can be predicted through basic analysis using financial statements. The results showed that the increase of the ending inventory has a negative relationship with future performance. This is because an artificially adjusted production level, regardless of future demand forecasts, is not a business strategy that can be continuously selected in the following period. In other words, an artificially adjusted production level is reversed in the following period, which has a negative impact on future performance. According to the earnings management literature, an artificially adjusted production level negatively affects future performance, because it can distort the firm's resource allocation and undermine its operating capacity (Graham et al., 2005 [31]; Roychowdhury, 2006 [19]; Cohen et al., 2008 [32]). As described above, there is a possibility that the changes in the ending inventory may provide conflicting meanings to users of accounting information as information reflecting a manager's private signals or the motivation of a manager's earnings management.

\subsection{Research Hypotheses}

Business strategy has a significant impact on financial status and future performance. We employ two categories (cost leadership or product differentiation strategy) of business strategy (Porter, 1985 [6]). A product differentiation strategy is a strategy that aims to obtain high prices by providing products that are differentiated from those of competitors. This strategy should be able to identify highly significant product characteristics to customers and provide differentiated products that reflect these characteristics. A product differentiation strategy requires continuous R\&D investment, superior manufacturing skills, and marketing capabilities to succeed in the market (Porter, 1985 [6]). A cost leadership strategy is a strategy to achieve a competitive advantage by supplying goods or services at low prices. This strategy requires thorough cost control to be successful and also seeks to achieve a cost advantage by using economies of scale and increasing production efficiency (Porter, 1985 [6]). 
In general, firms that employ a product differentiation strategy are highly dependent on technology, and these firms' technology excellence is a key factor in their survival and growth. Firms with product differentiation strategies seek to innovate products by developing new products or improving the performance and design of existing products. Therefore, these firms seek future growth through differentiated products, as a core business activity (Biggadike, 1979 [33]).

Meanwhile, managers perform sales manipulation to meet or beat the expected sales. Sales manipulation refers to the behavior of managers that attempts to increase sales during the current year in an effort to increase reported earnings. Table 1 presents the factors that have a negative (-) effect on future profitability. One is the factors that cause a negative (-) relationship between sales manipulation and future profitability. The other is the factors that occur when a firm with inventory accumulation does not sales manipulation. For sales manipulation, firms can increase current sales and earnings through price discounts or lenient credit conditions. However, these types of sales manipulation may have a negative (-) impact on future performance by damaging the brand value of the product and increasing future bad debt. Additionally, if a consumer purchases a product for future use at discount sales, the demand for the next period will decrease. This can have a negative impact on future profitability. Prior studies find that real activities manipulation increases profits in the current fiscal year, but undermines future profitability, because they are outside of optimal management activities (Gunny, 2010 [2]; Zang, 2012 [3]; Kim et al., 2009 [4]). The reason for the deterioration of future profitability due to sales manipulation, as a type of real earnings management, is that the expected loss from discount sales or lenient credit conditions is larger than the inventory holding costs, when the inventory is not sold.

Table 1. Future profitability impact.

\begin{tabular}{ll}
\hline \multicolumn{1}{c}{ Sales Manipulation } & \multicolumn{1}{c}{ Non-Sales Manipulation } \\
\hline - decrease in brand value & $\bullet$ increase in inventory holding costs \\
- difficulty of recovering the normal price & $\bullet$ loss due to inventory obsolescence \\
- decrease in future demand due to pre-buying & $\bullet$ failure to smooth operation of the production process \\
- increase in bad debt & $\bullet$ disruption in purchasing plan \\
\hline
\end{tabular}

Considering the association between sales manipulation and future profitability in terms of the strategy employed, firms that employ a product differentiation strategy are more likely to damage the brand value due to sales manipulation, because they supply expensive and differentiated products to the market. In addition, after selling products at discounted prices, product prices will suffer difficulties in recovering to normal prices, and demand for products in the following year is expected to markedly decline as a result of discount sales. On the other hand, since a cost leadership strategy is to supply products at low prices, there is a high possibility that the brand value is less damaged, and discount sales are very frequent. Therefore, it is easy for the product price to recover to its normal price. This strategy is also less effective in reducing the future demand because of less purchasing using discount sales than a product differentiation strategy.

Based on the above discussion, the negative effect of sales manipulation on future profitability is expected to be greater for a product differentiation strategy than for a cost leadership strategy, because the brand value is more damaged, and price recovery to normal is more difficult for the product differentiation strategy. Therefore, we set hypothesis 1 , as follows, to examine whether the effects of sales manipulation on firms' profitability differ according to firms' strategies:

Hypothesis 1 (H1). The negative (-) effects of sales manipulation on future profitability will be greater for product differentiation firms than for cost leadership firms.

Next, unlike normal sales, sales through price discounts or more lenient credit terms have a negative (-) impact on future profitability. The reason is that sales manipulation through price 
discounts or more lenient credit terms is outside of optimal management activities (Gunny, 2010 [2]; Zang, 2012 [3]; Kim et al., 2009 [4]). However, all sales manipulations may not negatively affect future profitability. If the future expected loss due to sales through price discounts or lenient credit conditions is less than the expected loss due to an increase in inventory holding costs and inventory obsolescence, in this case, sales manipulation will have a positive (+) impact, not a negative (-) impact, on future profitability. Therefore, our study divides sales manipulation that has a negative (-) effect on future profitability and sales manipulation (optimal sales manipulation) that does not negatively (-) affect future profitability. After separating it into two types, we examine how the two types of sales manipulation affect future profitability.

We define the sales manipulation of firms, where the ratio of the starting inventory to total assets is high and the ending inventory is reduced, as an optimal sales manipulation. Optimal sales manipulation reduces future expected losses due to an increase in the inventory holding costs and inventory obsolescence. The accumulation of inventory assets means a sluggish demand and weakening of firm competitiveness, which negatively affects the firm value. In other words, the increase of the ending inventory is regarded as a negative (-) signal in the market and shows a negative association with stock prices (Ou and Penman, 1989 [7]; Abarbanell and Bushee, 1997 [8]).

As mentioned above, if inventory piles up too much and inventory carrying costs and inventory obsolescence loss exceed the future loss from brand value damage and bad debt costs, an increase in sales by price discounts or lenient credit conditions will have a positive $(+)$ impact on future profitability. Therefore, sales manipulation, as a type of real earnings management, is expected to have a negative $(-)$ impact on future profitability, while optimal sales manipulation is expected to have a positive $(+)$ impact on future profitability. We set hypothesis 2, as follows, to examine whether the effects of sales manipulation on firms' profitability differ according to their inventory level:

Hypothesis 2 (H2). The optimal sales manipulation of firms, where the ratio of the stating inventory to total assets is higher and the ending inventory is reduced, will have a positive (+) impact on future profitability.

Finally, we examine how the effects of optimal sales manipulation on the future profitability differ according to a firm's strategy. Considering the association between optimal sales manipulation and future profitability in terms of strategy, firms that employ a product differentiation strategy have a significant increase in inventory holding costs when they do not employ optimal sales manipulation. They also have a heavy loss due to obsolescence of inventory assets. Furthermore, an increase in the accumulation of inventory assets is highly likely to cause an enormous hindrance to future production planning and operation. In particular, given the frequent launch of new models and new products in firms that employ a product differentiation strategy, selling old products through optimal sales manipulation is expected to have a more positive (+) impact on future profitability than not selling.

For example, if firms discount old products before launching a new product, they will lose as much as the discount than selling at the normal price. On the other hand, when a new product is released, demand for the old products declines, and firms will lose the opportunity to sell old products if they do not offer discounts. Therefore, the discount sale of old products becomes the optimal decision. The optimal sales manipulation is aimed at reducing future expected losses due to an increase in inventory holding costs and inventory obsolescence. The optimal sales manipulation of firms that employ a product differentiation strategy has a positive (+) effect on future profitability, because it does not deteriorate the brand value of the new product and has little effect on the price setting of the new product.

As mentioned above, given the frequent launch of new models and new products, firms that employ a product differentiation strategy are expected to have larger expected inventory losses due to an increase in inventory holding costs and inventory obsolescence, unlike firms that employ a cost leadership strategy. In addition, firms that employ a cost leadership strategy may have frequent price discounts due to price competition, and the launch of new products is likely to be less than that of 
firms that employ a product differentiation strategy. Therefore, we set hypothesis 3 , as follows, to examine whether the effects of optimal sales manipulation on firms' profitability differ according to a firm's strategy:

Hypothesis 3 (H3). The positive (+) effects of optimal sales manipulation on future profitability will be greater for product differentiation firms than for cost leadership firms.

\section{Research Design and Sample Selection}

\subsection{Classification of Strategy}

In general, there are two broad categories (cost leadership or product differentiation strategy) of a business strategy (Porter, 1985 [6]). Porter (1985) [6] argues that firms employ business strategies to compete effectively. Porter's (1985) [6] classification of business strategy is considered by many to be conceptually valid and is academically accepted (Hambrick, 1983 [1]; Dess and Davis, 1984 [34]). Thus, previous studies employed this classification (O'Brien, 2003[13]; Jermias, 2008 [9]).

In our study, the classification of strategy plays a very important role. Firms are classified by product differentiation firms or cost leadership firms by employing cluster analysis, as in previous studies (Singh and Agarwal, 2002 [35]; Jermias, 2008 [9]). Business strategy can be categorized in such a way that each variable is scored above a certain level (e.g., median or top $25 \%$ ). This method should be artificially set at a certain level and should not consider the interaction between three variables. Therefore, it is judged that statistical clustering analysis is more effective, and firms are classified into strategic archetypes using the partitioning technique. Cluster analysis classifies groups based on the similarity and differentiation of specific variables. We adopt the approach of Singh and Agarwal (2002) [35] and Jermias (2008) [9] and employ three classification variables: Asset utilization efficiency (total sales/total assets), premium price capability (gross margin/total sales), and R\&D intensity (R\&D expenses/total sales). Since business strategy is determined from a long-term, rather than a short-term, perspective, the variables use a three-year moving average. Since the scale of variables is different, cluster analysis is performed by standardizing the three variables.

Table 2 shows the difference in the expected values between the three variables used to classify the firm's strategic characteristics. Overall, product differentiation firms are expected to have a higher R\&D intensity, higher premium price capability, and lower asset utilization efficiency than cost leadership firms.

Table 2. Business strategy classification variables.

\begin{tabular}{|c|c|c|}
\hline Variables $\quad$ Strategy & Product Differentiation Strategy & Cost Leadership Strategy \\
\hline Asset utilization efficiency & Low & High \\
\hline Premium price capability & High & Low \\
\hline R\&D intensity & High & Low \\
\hline
\end{tabular}

\subsection{Measurement of Sales Manipulation and Optimal Sales Manipulation}

Financial information provides useful data on the future performance and cash flow of a firm. So, firm managers manage reported earnings to meet various incentives. Earnings management can be categorized into two: Accrual-based earnings management and real activities manipulation (sales manipulation, over-production, decreasing discretionary expenses). We use the concept of sales manipulation, one of the means of earnings management using real activities manipulation, proposed by Roychowdhury (2006) [19]. Sales manipulation refers to increasing sales and earnings during the current year by offering price discounts or more lenient credit terms. Firms can generate additional sales or accelerate sales from the next fiscal year into the current year by offering price discounts. The increased sales volumes are likely to disappear when the firm re-establishes the old 
prices. In addition, the increased sales as a result of the discounts are likely to lower margins. The lower margins due to the price discounts cause production costs, relative to sales, to be abnormally high (Roychowdhury, 2006 [19]). Therefore, the cash inflow per discounted sales is lower than the inflow per sales, without price discounts.

Another way to increase sales is to offer more lenient credit terms. Extending the installment period and offering credit terms at a lower interest rate toward the end of fiscal years are similar to offering price discounts. More lenient credit terms increase sales, but they lead to a lower cash inflow and higher bad debt costs than what is normally given at the sales level (Roychowdhury, 2006 [19]). As a result, sales manipulation, by offering price discounts or more lenient credit terms, leads to a lower current-period cash inflow.

In this study, we use the model, presented by Roychowdhury (2006) [19], to measure the abnormal level of cash flow of operations (CFO). To estimate the model, we run the following cross-sectional regression for every industry and year:

$$
C F O_{i, t} / A_{i, t-1}=\alpha_{0}+\alpha_{1} \frac{1}{A_{i, t-1}}+\beta_{1} \frac{S_{i, t}}{A_{i, t-1}}+\beta_{2} \frac{\Delta S_{i, t}}{A_{i, t-1}}+\varepsilon_{i, t}
$$

where $A_{i, t-1}$ is the total assets in the year, $t-1 ; S_{i, t}$ is the sales in the year, $t$; and $\Delta S_{i, t}$ is the change in net sales from year $t-1$ to $t$. The estimated residuals are our proxy for abnormal CFO and are multiplied by -1 to use as a measure of sales manipulation $\left(S M_{i, t}\right)$. The higher the value of $S M_{t}$, the more sales manipulation activity can be seen.

This study employs the logic of previous research that sales manipulation undermines future profitability (Gunny, 2010 [2]; Zang, 2012 [3]; Kim et al., 2009 [4]). However, all types of sales manipulation may not have a negative (-) impact on future profitability. The accumulation of inventory assets increases inventory holding costs and inventory obsolescence, which negatively affects future performance (Ou and Penman, 1989 [7]; Abarbanell and Bushee, 1997 [8]). Therefore, the sales manipulation performed by firms with a high proportion of the starting inventory and a decrease in the inventory during the current year is a rational decision, which takes into account the firm's situation rather than opportunistic behavior. In this case, since the decrease in margins due to price discounts or more lenient credit terms is smaller than the loss due to holding costs and obsolescence of inventory assets, sales manipulation is an optimal operating activity for a firm. In this study, we define the sales manipulation of firms, where the ratio of the starting inventory to total assets is higher than the median by year and the ending inventory is reduced, as an optimal sales manipulation. To test, a measure of an optimal sales manipulation is transformed into the indicator variable $\left(D_{o p}\right)$.

\subsection{Empirical Models}

First, we employ the following regression model to investigate the effects of sales manipulation $\left(S M_{i, t}\right)$ on future profitability. The basic model is:

$$
\begin{aligned}
A R O A_{i, t}+1=\beta_{0} & +\beta_{1} S M_{i, t}+\beta_{2} S I Z E_{i, t}+\beta_{3} B T M_{i, t}+\beta_{4} L E V_{i, t} \\
& +\beta_{5} A R O A_{i, t}+\sum Y D+\varepsilon_{i, t}
\end{aligned}
$$

where $A R O A_{i, t}$ is the industry-adjusted ROA, which equals the difference between firm-specific ROA and the median ROA for the same year and industry; $A R O A_{i, t+1}$ is the industry-adjusted ROA in the year, $t+1$; ROA is the net income divided by total assets; and $S M_{i, t}$ is a measure of sales manipulation. We employ the industry-adjusted ROA to control differences in the industrial concentration that may affect future profitability. In the model (2), if the coefficient $\left(\beta_{1}\right)$ of $S M_{i, t}$ shows a significant negative (-) value, this indicates that sales manipulation negatively affects future profitability as earnings management.

We include various control variables associated with future profitability. $S I Z E_{i, t}$ is the natural logarithm of total assets, which controls the size effect. $B T M_{i, t}$ is the book value of equity divided by 
the market value of equity, which controls the growth opportunities. $L E V_{i, t}$ is the financial leverage, determined by the ratio of total debt to total assets, which controls the financial risk of a firm. $A R O A_{i, t}$ is included, because the current industry-adjusted ROA is associated with the future industry-adjusted ROA. Finally, year dummies $(Y D)$ is included to control the effects of years on future profitability.

For sales manipulation, firms can increase current sales and earnings through increased price discounts or more lenient credit conditions. However, this sales manipulation may have a negative (-) impact on future performance by damaging the brand value of the product and increasing future bad debt. We examine whether the effects of sales manipulation on future profitability differ according to firms' strategies. We employ the following regression model to test hypothesis 1 :

$$
\begin{gathered}
A R O A_{i, t+1}=\beta_{0}+\beta_{1} S M_{i, t}+\beta_{2} D_{p d}+\beta_{3} S M_{i, t} \times D_{p d}+\beta_{4} S I Z E_{i, t}+\beta_{5} B T M_{i, t} \\
+\beta_{6} L E V_{i, t}+\beta_{7} A R O A_{i, t}+\sum Y D+\varepsilon_{i, t}
\end{gathered}
$$

where $A R O A_{i, t}$ is the industry-adjusted ROA, which equals the difference between the firm-specific ROA and the median ROA for the same year and industry; $A R O A_{i, t+1}$ is the industry-adjusted ROA in the year, $t+1 ; S M_{i, t}$ is a measure of sales manipulation; $D_{p d}$ is an indicator variable that, if firms employ a product differentiation strategy, takes the value of 1 , or otherwise 0 ; and $S M_{i, t} \times D_{p d}$ is the interest variable, which is the interaction variable between $D_{p d}$ and $S M_{i, t}$. The coefficient $\left(\beta_{3}\right)$ of $S M_{i, t} \times D_{p d}$ indicates the differences in the effects of sales manipulation on future profitability between product differentiation firms and cost leadership firms. If the coefficient $\left(\beta_{3}\right)$ of $S M_{i, t} \times D_{p d}$ shows a significant negative (-) value, this means that the negative (-) effects of sales manipulation on future profitability is greater for product differentiation firms than for cost leadership firms. In other words, firms that employ a product differentiation strategy are more likely to damage their brand value due to sales manipulation, because they supply expensive and differentiated products to the market. The control variables employ the same variables as model (2).

Next, previous studies found that sales manipulations increase earnings in the current period, but undermine future profitability, because they are outside of optimal management activities (Gunny, 2010 [2]; Zang, 2012 [3]; Kim et al., 2009 [4]). However, all sales manipulations may not negatively (-) affect future profitability. We examine whether the effects of sales manipulation on future profitability differ depending on the firm's situation. We employ the following regression model to test hypothesis 2:

$$
\begin{gathered}
A R O A_{i, t+1}=\beta_{0}+\beta_{1} S M_{i, t}+\beta_{2} D_{o p}+\beta_{3} S M_{i, t} \times D_{o p}+\beta_{4} S I Z E_{i, t}+\beta_{5} B T M i_{i, t} \\
+\beta_{6} L E V_{i, t}+\beta_{7} A R O A_{i, t}+\sum Y D+\varepsilon_{i, t}
\end{gathered}
$$

where $A R O A_{t}$ is the industry-adjusted ROA, which equals the difference between the firm-specific ROA and the median ROA for the same year and industry; $A R O A_{t+1}$ is the industry-adjusted ROA in the year, $t+1 ; S M_{t}$ is a measure of sales manipulation; $D_{o p}$ is an indicator variable that, if firms employ an optimal sales manipulation, takes the value of 1 , or otherwise 0 ; and $S M_{i, t} \times D_{o p}$ is the interest variable, which is the interaction variable between $D_{o p}$ and $S M_{i, t}$. The coefficient $\left(\beta_{3}\right)$ of $S M_{i, t} \times D_{o p}$ indicates the differences in the effects of sales manipulation on future profitability between firms that employ an optimal sales manipulation and those that do not. If the coefficient $\left(\beta_{3}\right)$ of $S M_{i, t} \times D_{o p}$ shows a significant positive $(+)$ value, this means that the optimal sales manipulation has a positive $(+)$ impact on future profitability. Optimal sales manipulation involves reducing future expected losses due to an increase in inventory holding costs and inventory obsolescence. Therefore, the optimal sales manipulation is expected to have a positive (+) impact on future profitability. The control variables employ the same variables as model (2).

Finally, we examine how the effects of optimal sales manipulation on the future profitability differ according to the firm's strategies. To test hypothesis 3, we estimate model (4) for each group by classifying product differentiation firms and cost leadership firms. Then, we examine whether there are differences in the relative size between the $\left(\beta_{1}+\beta_{3}\right)$ of the product differentiation group and $\left(\beta_{1}+\beta_{3}\right)$ of the cost leadership group. In order to directly determine whether there are significant 
differences between the two regression coefficients, a statistical method is needed. For this, we employ the parallelism test, proposed by Hollander (1970) [36]. This test is a method to examine whether there are relatively significant differences between each regression coefficient of the two regression models. On the other hand, the F-test is a method to examine whether there are significant differences between the regression coefficients of two variables included in one regression model.

\subsection{Samples and Data}

The sample used in our study consists of firms in the manufacturing industries, listed on the Koran Exchange (KRX), and that have a fiscal year ending in December. The manufacturing industry is selected as the sample, because the use of a single industry minimizes the problem of sample heterogeneity (Ginsberg and Venkatraman, 1985 [37]; Yuen and Moores, 2001 [38]). We obtain financial data from the FN Data-Guide, provided by the FN Guide, and TS-2000 database, provided by the Korea Listed Companies Association (KLCA). Financial firms are excluded, because their operating characteristics and financial statement accounts are different from those of manufacturing firms. For comparability, we exclude firms with impaired capital and firms without the financial data needed for analysis. We require at least 9 observations for each industry-year grouping. Finally, to limit the influence of extreme observations, all continuous variables are winsorized at the top and bottom $1 \%$ level. The final sample consists of 8186 firm-year observations, from 1995 to 2016.

Table 3 shows the industry distribution of the sample. The most frequent industry is the manufacture of chemical materials and chemical products, which account for $12.11 \%$ of the final sample. Next, primary metal accounts for $7.85 \%$; cars and trailers account for $7.34 \%$; and electronic components, computers, video, sound, and communication equipment account for $7.22 \%$.

Table 3. Industry distribution of the sample.

\begin{tabular}{lcc}
\hline \multicolumn{1}{c}{ Industry } & N & Percentage (\%) \\
\hline Manufacture of food products & 471 & $5.75 \%$ \\
Manufacture of textile products, excluding clothing & 165 & $2.02 \%$ \\
Manufacture of clothing, clothing accessories, and fur products & 202 & $2.47 \%$ \\
Manufacture of pulp, paper, and paper products & 325 & $3.97 \%$ \\
Manufacture of chemical materials and chemical products, & 991 & $12.11 \%$ \\
excluding medicines & 491 & $6.00 \%$ \\
Manufacture of medical materials and medicines & 279 & $3.41 \%$ \\
Manufacture of rubber and plastic products & 353 & $4.31 \%$ \\
Manufacture of non-metallic mineral products & 643 & $7.85 \%$ \\
Manufacture of primary metal & 60 & $0.73 \%$ \\
Manufacture of metal-processed products, excluding & & \\
machinery and furniture & 591 & $7.22 \%$ \\
Manufacture of electronic components, computers, video, and & 255 & $3.12 \%$ \\
sound and communication equipment & 380 & $4.64 \%$ \\
Manufacture of electrical equipment & 601 & $7.34 \%$ \\
Manufacture of other machines and equipment & 35 & $0.43 \%$ \\
Manufacture of cars and trailers & 115 & $1.40 \%$ \\
Manufacture of other transportation equipment & 497 & $6.07 \%$ \\
Electricity, gas, steam, and air conditioning supply industries & 638 & $7.79 \%$ \\
Comprehensive construction industries & 116 & $1.42 \%$ \\
Wholesale trade and commission trade industries & 76 & $0.93 \%$ \\
Retail, excluding cars & 902 & $11.02 \%$ \\
Land transportation and pipeline transportation industries & 8186 & $100 \%$ \\
Professional services & &
\end{tabular}




\section{Empirical Results}

\subsection{Results of Strategy Classification}

Firms are classified into product differentiation firms or cost leadership firms by employing cluster analysis, as in previous studies (Singh and Agarwal, 2002 [35]; Jermias, 2008 [9]). Cluster analysis is conducted based on the asset utilization efficiency (total sales/total assets), premium price capability (gross margin/total sales), and R\&D intensity (R\&D expenses/total sales). Table 4 reports descriptive statistics of the three variables for each strategy, $t$-test statistic, and Wilcoxon $z$ statistic to verify the differences in variables. The product differentiation strategy has significantly higher ratios of premium price capability $(t=27.11, z=25.95)$ and R\&D intensity $(t=5.42, z=17.46)$, but significantly lower ratios of asset utilization efficiency $(t=-17.35, z=-21.63)$, as compared to the cost leadership strategy. Overall, the product differentiation strategy has a lower asset utilization efficiency and higher premium price capability and R\&D intensity than the cost leadership strategy. These results are consistent with the general strategy characteristics.

Table 4. Industry distribution of the sample.

\begin{tabular}{|c|c|c|c|c|c|c|}
\hline \multirow[t]{2}{*}{ Cluster Variables } & \multicolumn{2}{|c|}{$\begin{array}{l}\text { Product Differentiation } \\
\text { Strategy }(\mathrm{N}=1185)\end{array}$} & \multicolumn{2}{|c|}{$\begin{array}{l}\text { Cost Leadership } \\
\text { Strategy }(\mathrm{N}=3852)\end{array}$} & \multicolumn{2}{|c|}{ Statistical Differences } \\
\hline & Mean & Median & Mean & Median & $t$-Test & Wilcoxon $z$ \\
\hline Asset utilization efficiency & 0.7495 & 0.7441 & 1.1109 & 0.9521 & -17.35 & -21.63 \\
\hline Premium price capability & 0.3624 & 0.2442 & 0.1672 & 0.1463 & 27.11 & 25.95 \\
\hline$R \& D$ intensity & 0.0373 & 0.0127 & 0.0094 & 0.0036 & 5.42 & 17.46 \\
\hline
\end{tabular}

Notes: Asset utilization efficiency is measured by the ratio of total sales to total assets. The premium price capability is measured by the ratio of gross margin to total sales. The R\&D intensity is measured by the ratio of R\&D expenses to total sales.

\subsection{Descriptive Statistics and Correlations}

Table 5 reports the descriptive statistics of variables. The industry-adjusted ROA $\left(A R O A_{i, t}\right)$ has a mean (median) value of $-0.008(0.000)$. Since this variable is the difference between the firm-specific ROA and the median ROA for the same year and industry, the values of the mean and median are close to zero. The firm size (SIZE $E_{i, t}$ ) has a mean (median) of 19.52 (19.29), which indicates a slightly right-skewed distribution. The ratio of book-to-market $\left(B T M_{i, t}\right)$ has a mean (median) value of 1.797 (1.404), which implies that the market value of equity is less than its book value. The distribution of $L E V_{i, t}$ stays stable around the median value of 0.482 . In addition, firms that employ optimal sales manipulation account for about $15.5 \%$ of the sample, and product differentiation firms account for about $22.6 \%$ of the sample.

Table 6 reports the correlations between the variables used in the empirical test. The correlation coefficient between $A R O A_{i, t+1}$ and $A R O A_{i, t}$ is 0.477 , which is very high. This can be attributed to the high persistence of earnings. The future profitability $\left(A R O A_{i, t}+1\right)$ shows significant positive $(+)$ correlations with firm size $\left(S I Z E_{i, t}\right)$ and significant negative $(-)$ correlations with the book-to-market ratio $\left(B T M_{i, t}\right)$, debt ratio $\left(L E V_{i, t}\right)$, and sales manipulation $\left(S M_{i, t}\right)$. The results show that firms with a larger firm size tend to have a higher future profitability $\left(A R O A_{i, t+1}\right)$, and firms with a larger book-to-market ratio, debt ratio, and sales manipulation tend to have a lower future profitability $\left(A R O A_{i, t+1}\right)$. Since the above results do not control the influence of other variables on future profitability, we perform multiple regression analysis, including various control variables. 
Table 5. Descriptive statistics.

\begin{tabular}{ccccccccc}
\hline Variable & $\mathbf{N}$ & Mean & Std. & Min & $\mathbf{2 5 \%}$ & Median & $\mathbf{7 5 \%}$ & Max \\
\hline$A R O A_{i, t+1}$ & 8186 & -0.009 & 0.077 & -0.376 & -0.028 & -0.001 & 0.026 & 0.181 \\
$A R O A_{i, t}$ & 8186 & -0.008 & 0.077 & -0.374 & -0.027 & 0 & 0.026 & 0.185 \\
$S_{Z Z E_{i, t}}$ & 8186 & 19.52 & 1.44 & 16.80 & 18.49 & 19.29 & 20.31 & 23.80 \\
$B T M_{i, t}$ & 8186 & 1.797 & 1.428 & -0.198 & 0.834 & 1.404 & 2.306 & 7.775 \\
$L E V_{i, t}$ & 8186 & 0.481 & 0.209 & 0.048 & 0.325 & 0.482 & 0.628 & 1.016 \\
$D_{p d}$ & 8186 & 0.226 & 0.418 & 0 & 0 & 0 & 0 & 1 \\
$S M_{i, t}$ & 8186 & -0.002 & 0.063 & -0.168 & -0.040 & -0.004 & 0.034 & 0.179 \\
$D_{o p}$ & 8186 & 0.155 & 0.362 & 0 & 0 & 0 & 0 & 1 \\
\hline
\end{tabular}

Variable definitions: $A R O A_{i, t}$ is the industry-adjusted ROA, which equals the difference between the firm-specific ROA and the median ROA for the same year and industry; $A R O A_{i, t+1}$ is the industry-adjusted ROA in the year, $t+1$; ROA is the net income divided by total assets; $\operatorname{SIZE}_{i, t}$ is the natural logarithm of total assets, which controls the size effects; $B T M_{i, t}$ is the book value of equity divided by the market value of equity, which controls the growth opportunities; $L E V_{i, t}$ is the financial leverage, determined by the ratio of total debt to total assets, which controls the financial risk of a firm; $S M_{i, t}$ is a measure of sales manipulation, which is the residuals from model (1); $D_{p d}$ is an indicator variable that takes the value of 1 if firms employ a product differentiation strategy, or otherwise 0 ; and $D_{o p}$ is an indicator variable that takes the value of 1 if firms employ an optimal sales manipulation, or otherwise 0 .

Table 6. Correlations between the variables.

\begin{tabular}{|c|c|c|c|c|c|c|c|c|}
\hline & $A R O A_{i, t+1}$ & $A R O A_{i, t}$ & $S I Z E_{i, t}$ & $B T M_{i, t}$ & $L E V_{i, t}$ & $D_{o p}$ & $S M_{i, t}$ & $S M_{i, t} \times D_{o p}$ \\
\hline$A R O A_{i, t+1}$ & 1 & & & & & & & \\
\hline$A R O A_{i, t}$ & 0.477 & 1 & & & & & & \\
\hline$S I Z E_{i, t}$ & 0.078 & 0.104 & 1 & & & & & \\
\hline$B T M_{i, t}$ & -0.134 & -0.061 & -0.005 & 1 & & & & \\
\hline$L E V_{i, t}$ & -0.215 & -0.333 & 0.121 & -0.022 & 1 & & & \\
\hline$D_{o p}$ & 0.000 & -0.028 & -0.062 & 0.072 & 0.025 & 1 & & \\
\hline$S M_{i, t}$ & -0.173 & -0.209 & -0.089 & 0.040 & 0.237 & 0.054 & 1 & \\
\hline$S M_{i, t} \times D_{o p}$ & -0.037 & -0.079 & -0.024 & 0.018 & 0.070 & 0.087 & 0.400 & 1 \\
\hline
\end{tabular}

Notes: This table presents Pearson correlations. Coefficients shown in bold are significant, at $p<0.05$ (two-tailed test). Please see Table 5 for variable definitions.

\subsection{Multivariate Results}

\subsubsection{Results for Business Strategy (H1)}

Table 7 shows the effects of business strategy on the association between sales manipulation and future profitability. First, regression 1 (without interaction terms) reports that the coefficient for sales manipulation $\left(S M_{i, t}\right)$ is -0.070 and is statistically significant. This result is consistent with the results of previous studies, in which it was found that sales manipulation negatively affects future profitability. Regression 2 (with interaction terms) shows the interactive effects of business strategy on the sales manipulation-future profitability relationship. The coefficient, $\beta_{5}$, of regression 2 is negative and statistically significant, showing that the sales manipulation of a cost leadership firm negatively affects future profitability.

Hypothesis 1 predicts that the association between sales manipulation and future profitability will be more negative for a product differentiation strategy than for a cost leadership strategy. The results show that the coefficient of $S M_{i, t} \times D_{p d}$ is negative and statistically significant $\left(\beta_{7}=-0.058, p<0.01\right)$. The results indicate that the association between sales manipulation and future profitability is more negative for product differentiation firms than for cost leadership firms. These results are consistent with hypothesis 1 , indicating that firms that employ a product differentiation strategy are more likely to damage the brand value due to sales manipulation, because they supply expensive and differentiated products to the market. The above results are consistent with the results of Jermias (2008) [9], which indicate that the leverage-performance relationship is more negative (-) for product differentiation firms than for cost leadership firms. In sum, managers need to consider the business strategy and the environment in which a firm operates when managing reported earnings in regards to a firm's 
sustainability. With respect to the control variable, we find that $A R O A_{i, t}$ and $S I Z E_{i, t}$ have positive coefficients, and $B T M_{i, t}$ and $L E V_{i, t}$ have negative coefficients.

Table 7. Analysis of the relationship between sales manipulation and future profitability by strategy.

\begin{tabular}{|c|c|c|c|c|}
\hline \multicolumn{5}{|c|}{$\begin{array}{c}A R O A_{i, t+1}=\beta_{0}+\beta_{1} S M_{i, t}+\beta_{2} D_{p d}+\beta_{3} S M_{i, t} \times D_{p d}+\beta_{4} S I Z E_{i, t}+\beta_{5} B T M_{i, t}+\beta_{6} L E V_{i, t}+\beta_{7} A R O A_{i, t}+ \\
\sum Y D+\varepsilon_{i, t}\end{array}$} \\
\hline \multirow[t]{2}{*}{ Variable } & \multicolumn{2}{|c|}{$\begin{array}{c}\text { Regression } 1 \\
\text { (Without Interaction Terms) }\end{array}$} & \multicolumn{2}{|c|}{$\begin{array}{l}\text { Regression } 2 \\
\text { (With Interaction Terms) }\end{array}$} \\
\hline & Coefficient & $t$-Value & Coefficient & $t$-Value \\
\hline Intercept & -0.034 & $-3.15^{* * *}$ & -0.034 & $-3.12 * * *$ \\
\hline$A R O A_{i, t}$ & 0.427 & $40.09 * * *$ & 0.422 & $39.43^{* * *}$ \\
\hline$S I Z E_{i, t}$ & 0.003 & $4.85^{* * *}$ & 0.003 & $5.11^{* * *}$ \\
\hline$B T M_{i, t}$ & -0.007 & $-12.81^{* * *}$ & -0.008 & $-13.09 * * *$ \\
\hline$L E V_{i, t}$ & -0.031 & $-7.21^{* * *}$ & -0.035 & $-7.83^{* * *}$ \\
\hline$S M_{i, t}$ & -0.070 & $-5.65^{* * *}$ & -0.058 & $-4.22 * * *$ \\
\hline$D_{p d}$ & & & -0.009 & $-4.31^{* * *}$ \\
\hline$S M_{i, t} \times D_{p d}$ & & & -0.058 & $-3.21 * * *$ \\
\hline Year Dummy & \multicolumn{2}{|c|}{ Included } & \multicolumn{2}{|c|}{ Included } \\
\hline $\operatorname{Adj} \cdot R^{2}$ & \multicolumn{2}{|c|}{0.2529} & \multicolumn{2}{|c|}{0.2547} \\
\hline F-value & \multicolumn{2}{|c|}{116.46} & \multicolumn{2}{|c|}{108.6} \\
\hline$\left(S M_{i, t}+S M_{i, t} \times D_{p d}\right)$ & & & -0.116 & $F=19.59$ \\
\hline
\end{tabular}

Note: This table reports the effects of business strategy on the association between sales manipulation and future profitability. ${ }^{* * *}$ represents significance at the 0.01 level. Please see Table 5 for variable definitions.

\subsubsection{Results for Optimal Sales Manipulation (H2)}

Table 8 shows the interactive effects of an optimal sales manipulation on the sales manipulation-future profitability relationship. The coefficient for sales manipulation $\left(S M_{i, t}\right)$ is -0.087 and is statistically significant, indicating that sales manipulation negatively affects future profitability. The results show that the coefficient of $S M_{i, t} \times D_{o p}$ is negative and statistically significant $\left(\beta_{7}=0.097, p<0.01\right)$. These results indicate that the sales manipulation performed by firms with a high proportion of the starting inventory and a decrease in the ending inventory during the current year has a positive (+) impact on future profitability. The above results are consistent with hypothesis 2 , implying that, for firms with accumulated inventory, it is best to reduce losses due to holding costs and the obsolescence of the inventory. In the situation where inventory is accumulated, sales manipulation can be used as a means of an optimal operating activity, increasing a firm's sustainability. With respect to the control variable, we find that $A R O A_{i, t}$ and $S I Z E_{i, t}$ have positive coefficients, and $B T M_{i, t}$ and $L E V_{i, t}$ have negative coefficients.

\subsubsection{Results for Business Strategy and Optimal Sales Manipulation (H3)}

Table 9 shows the effects of business strategy on the association between an optimal sales manipulation and future profitability. The results for the product differentiation sample are reported in the first column of Table 9. The regression coefficient $\left(S M_{i, t}+S M_{i, t} \times D_{o p}\right)$ for the effects of an optimal sales manipulation of a product differentiation firm on future profitability is 0.144 , which is a statistically significant positive (+) value. This means that an optimal sales manipulation of a product differentiation firm has a positive effect on future profitability. 
Table 8. Analysis of the relationship between optimal sales manipulation and future profitability.

\begin{tabular}{ccc}
\hline AROA $_{i, t+1}=\beta_{0}+\beta_{1} S M_{i, t}+\beta_{2} D_{o p}+\beta_{3} S M_{i, t} \times D_{o p}+\beta_{4} S I Z E_{i, t}+$ \\
$\beta_{5} B T M_{i, t}+\beta_{6} L E V_{i, t}+\beta_{7} A R O A_{i, t}+\sum Y D+\varepsilon_{i, t}$ \\
\hline Variable & Coefficient & $t$-Value \\
\hline Intercept & -0.037 & $-3.36^{* * *}$ \\
$A R O A_{i, t}$ & 0.426 & $40.03^{* * *}$ \\
$S I Z E_{i, t}$ & 0.003 & $5.00^{* * *}$ \\
$B T M_{i, t}$ & -0.008 & $-13.03^{* * *}$ \\
$L E V_{i, t}$ & -0.031 & $-7.15^{* * *}$ \\
$S M_{i, t}$ & -0.087 & $-6.51^{* * *}$ \\
$D_{o p}$ & 0.006 & $2.76^{* * *}$ \\
$S M_{i, t} \times D_{o p}$ & 0.097 & $2.72^{* * *}$ \\
\hline Year Dummy & \multicolumn{3}{|}{ Included } \\
\hline Adj. $R^{2}$ & 0.2537 \\
\hline F-value & 108.04 \\
\hline$\left.S M_{i, t}+S M_{i, t} \times D_{o p}\right)$ & 0.010 \\
\hline
\end{tabular}

Note: This table reports the association between optimal sales manipulation and future profitability. ${ }^{* * *}$ represents significance at the 0.01 level. Please see Table 5 for variable definitions.

Table 9. Analysis of the relationship between optimal sales manipulation and future profitability by strategy.

\begin{tabular}{|c|c|c|c|c|}
\hline \multicolumn{5}{|c|}{$\begin{array}{c}A R O A_{i, t+1}=\beta_{0}+\beta_{1} S M_{i, t}+\beta_{2} D_{o p}+\beta_{3} S M_{i, t} \times D_{o p}+\beta_{4} S I Z E_{i, t}+\beta_{5} B T M_{i, t}+\beta_{6} L E V_{i, t}+\beta_{7} A R O A_{i, t}+ \\
\sum Y D+\varepsilon_{i, t}\end{array}$} \\
\hline \multirow{2}{*}{ Variable } & \multicolumn{2}{|c|}{ Product Differentiation (N = 1848) } & \multicolumn{2}{|c|}{ Cost Leadership $(\mathrm{N}=6338)$} \\
\hline & Coefficient & $t$-Value & Coefficient & $t$-Value \\
\hline Intercept & -0.036 & -1.55 & -0.036 & $-2.92 * * *$ \\
\hline$A R O A_{i, t}$ & 0.519 & $22.06^{* * *}$ & 0.394 & $32.98^{* * *}$ \\
\hline$S I Z E_{i, t}{ }^{\prime \imath}$ & 0.003 & $2.72 * * *$ & 0.003 & $4.19^{* * *}$ \\
\hline$B T M_{i, t}^{l, t}$ & -0.010 & $-7.03 * * *$ & -0.007 & $-11.44^{* * *}$ \\
\hline$L E V_{i, t}$ & -0.050 & $-5.37^{* * *}$ & -0.029 & $-5.71^{* * *}$ \\
\hline$S M_{i, t}$ & -0.091 & $-3.01^{* * *}$ & -0.081 & $-5.44^{* * *}$ \\
\hline$D_{o p}$ & 0.002 & 0.46 & 0.006 & $2.71^{* * *}$ \\
\hline$S M_{i, t} \times D_{o p}$ & 0.235 & $3.09^{* * *}$ & 0.060 & $1.70 *$ \\
\hline Year Dummy & \multicolumn{2}{|c|}{ Included } & \multicolumn{2}{|c|}{ Included } \\
\hline Adj. $R^{2}$ & \multicolumn{2}{|c|}{0.3451} & \multicolumn{2}{|c|}{0.2301} \\
\hline F-value & \multicolumn{2}{|c|}{38.44} & \multicolumn{2}{|c|}{73.8} \\
\hline \multirow{2}{*}{$\left(S M_{i, t}+S M_{i, t} \times D_{o p}\right)$} & 0.144 & $\mathrm{~F}=4.11$ & -0.021 & $\mathrm{~F}=0.4$ \\
\hline & \multicolumn{4}{|c|}{$\begin{array}{c}\mathrm{PD}\left(S M_{i, t}+S M_{i, t} \times D_{o p}\right)-\mathrm{CL}\left(S M_{i, t}+S M_{i, t} \times D_{o p}\right) \\
\text { Coefficient }=0.144 \mathrm{~F}=4.62\end{array}$} \\
\hline
\end{tabular}

Note: This table reports the effects of business strategy on the association between optimal sales manipulation and future profitability. ${ }^{* * *},{ }^{*}$ represent significance at the 0.01 and 0.1 levels, respectively. Please see Table 5 for variable definitions.

The results for the cost leadership sample are reported in the second column of Table 9. The regression coefficient $\left(S M_{i, t}+S M_{i, t} \times D_{o p}\right)$ for the effects of an optimal sales manipulation of a cost leadership firm on future profitability is -0.021 , which is not statistically significant. An optimal sales manipulation aims to reduce future expected losses due to an increase in inventory holding costs and inventory obsolescence. These results suggest that cost leadership firms have relatively less future expected losses by an increase in inventory holding costs and inventory obsolescence, than product differentiation firms.

Hypothesis 3 predicts that the association between an optimal sales manipulation and future profitability will be more positive for product differentiation firms than for cost leadership firms. 
Thus, we examine whether there are differences in the relative size between the coefficients of $\left(S M_{i, t}\right.$ $\left.+S M_{i, t} \times D_{o p}\right)$ of the product differentiation group and the cost leadership group. The results show that the association between an optimal sales manipulation and future profitability is more positive for product differentiation firms than for cost leadership firms. Since product differentiators provide unique products and services, their premium price capability (gross margin/sales) is higher than that of cost leaders (Singh and Agarwal, 2002 [35]). Therefore, an optimal sales manipulation of product differentiators has a greater influence on the future profitability than that of cost leaders. In sum, an optimal sales manipulation of product differentiators can be seen as closer to their core management activities than that of cost leaders.

\subsection{Additional Analysis}

In addition to the main analysis, we perform another analysis in two parts. First, the sales manipulation $\left(S M_{i, t}\right)$ variable is transformed into a dummy variable. We define that, if the value of $S M_{t}$ is greater than zero, the real activities manipulation is done by the manager. We re-estimate regression model (4) using the $S M_{i, t}$ variable, which is transformed into a dummy variable. In un-tabulated tests, the results of the analysis are almost similar to those of the analysis of the sales manipulation variable as a continuous variable. The results show that the coefficient of $S M_{i, t}\left(\beta_{5}=-0.057, p<0.01\right)$ and $S M_{i, t} \times D_{o p}\left(\beta_{7}=0.056, p<0.05\right)$ is negative $(-)$ and statistically significant. These results are consistent with hypothesis 2 , indicating that the sales manipulation performed by firms with a high proportion of the starting inventory and a decrease in the inventory during the current year is an optimal operating activity.

Second, we extend the future profitability variable to the $t+2$ period and perform an additional analysis. We re-estimate regression model (4) using the $A R O A_{t}+2$ variable, which extends to the $t+2$ period. The coefficient of $S M_{i, t}\left(\beta_{5}=-0.094, p<0.01\right)$ is negative $(-)$ and statistically significant. This indicates that sales manipulation negatively affects profitability even after two years. The coefficient of $S M_{i, t} \times D_{o p}\left(\beta_{7}=0.056, p<0.10\right)$ is negative $(-)$ and statistically significant. This means that the effect of optimal sales manipulation, which reduces future expected losses by an increase in inventory holding costs and inventory obsolescence, appears a little after two years. The adjusted $R^{2}$ is $11.2 \%$, which is lower than the analysis using $A R O A_{t+1}$.

In sum, sales manipulation increases earnings in the current fiscal year, but undermines future profitability, because it is outside of optimal management activities (Gunny, 2010 [2]; Zang, 2012 [3]; Kim et al., 2009 [4]). However, the optimal sales manipulation has a positive (+) impact, rather than a negative (-) impact, on future profitability, because it reduces future expected losses due to an increase in inventory holding costs and inventory obsolescence.

\section{Discussion and Conclusions}

In this study, we were interested in sales manipulation relating to corporate sustainability. Thus, we investigated the effects of the business strategy and a firm's situation on the relationship between sales manipulation and future profitability. As hypothesized, the results indicated that business strategy does affect the sales manipulation-profitability relationship such that it is more negative for product differentiation firms than for cost leadership firms. The results are consistent with the view that the leverage-performance relationship is more negative for product differentiation firms than for cost leadership firms (Jermias, 2008 [9]). We suggest that managers need to consider the business strategy and the environment in which a firm operates when managing reported earnings, because the costs and benefits of sales manipulation depend on these factors.

Next, our results showed that all sales manipulations may not negatively affect future profitability. In the situation where inventory is accumulated, sales manipulation has a positive impact on future profitability by reducing expected losses due to inventory holding costs and inventory obsolescence. This is inconsistent with the results made by Gunny (2010) [2] and Zang (2012) [3] that sales manipulation has a negative impact on future profitability. We show that the effects of sales manipulation on future 
profitability can be changed positively, depending on a firm's situation. In this regard, this study devised the concept of an optimal sales manipulation from the cumulative situation of a firm's inventory. Additionally, the results show that the positive effects of an optimal sales manipulation on future profitability is greater in product differentiation firms. Optimal sales manipulation of product differentiation firms can be seen as further increasing a firm's sustainability. Unlike in previous studies, we addressed the positive aspects of an optimal sales manipulation on future profitability.

The limitations of our study are as follows. First, there is the problem of omitted variables in the empirical model of future profitability. Second, this study does not completely rule out the problem of arbitrariness in distinguishing the optimal sales manipulation and grouping the business strategy. In sum, our study shows that sales manipulation has different effects on future profitability, depending on the strategy. In addition, we showed that sales manipulation can turn into an optimal operating activity depending on a firm's situation. This study is not only helpful in designing pricing policies in practice, but will also be useful for financial analysts and investors in predicting a firm's performance. Future research can be extended to other types of real activities manipulation, beyond sales manipulation.

Author Contributions: Formal analysis, H.D.Y.; Writing-original draft, S.P.; Writing-review and editing, J.K.

Funding: The APC was funded by Hanyang University.

Conflicts of Interest: The authors declare no conflict of interest.

\section{References}

1. Hambrick, D.C. High Profit Strategies in Mature Capital Goods Industries: A Contingency Approach. Acad. Manag. J. 1983, 26, 687-707.

2. Gunny, K.A. The Relation Between Earnings Management Using Real Activities Manipulation and Future Performance: Evidence from Meeting Earnings Benchmarks. Contemp. Account. Res. 2010, 27, 855-888. [CrossRef]

3. Zang, A.Y. Evidence on the Trade-Off between Real Activities Manipulation and Accrual-Based Earnings Management. Account. Rev. 2012, 87, 675-703. [CrossRef]

4. Kim, J.H.; Bae, J.H.; Goh, J.M. The effect of real earnings management on long term performance. Korean Account. Rev. 2009, 34, 31-70.

5. Chun, S.B.; Kwon, H.J.; Kim, M.I.; Kim, S.H.; Lee, A.Y. Financial reporting patterns of Korean firms: Based on the survey of chief financial officers. Korean Account. J. 2012, 21, 97-132.

6. Porter, M.E. Competitive Advantage; Free Press: New York, NY, USA, 1985; ISBN 978-0-684-84146-5.

7. Ou, J.A.; Penman, S.H. Financial statement analysis and the prediction of stock returns. J. Account. Econ. 1989, 11, 295-329. [CrossRef]

8. Abarbanell, J.S.; Bushee, B.J. Fundamental Analysis, Future Earnings, and Stock Prices. J. Account. Res. 1997, 35, 1-24. [CrossRef]

9. Jermias, J. The relative influence of competitive intensity and business strategy on the relationship between financial leverage and performance. Br. Account. Rev. 2008, 40, 71-86. [CrossRef]

10. Day, G.S.; Wensley, R. Assessing Advantage: A Framework for Diagnosing Competitive Superiority. J. Mark. 1988, 52, 1. [CrossRef]

11. Zahra, S.A. Technology strategy and new venture performance: A study of corporate-sponsored and independent biotechnology ventures. J. Bus. Ventur. 1996, 11, 289-321. [CrossRef]

12. Kim, G.; Han, S.S. The performance and implications of venture strategic typology. J. Ent. Ven. Stud. 2003, 6, $3-24$.

13. O'Brien, J.P. The capital structure implications of pursuing a strategy of innovation. Strat. Manag. J. 2003, 24, 415-431. [CrossRef]

14. Selling, T.I.; Stickney, C.P. The Effects of Business Environment and Strategy on a Firm's Rate of Return on Assets. Financ. Anal. J. 1989, 45, 43-52. [CrossRef]

15. Yi, H.D.; Lee, S.R.; Hon, S.S. Firm's strategy and future profitability. Korean Account. J. 2010, 19, 67-88.

16. Yi, H.D.; Park, S.B. The effects of business strategy on the association between R\&D intensity and future financial performance. Korean Account. J. 2014, 23, 115-143. 
17. Healy, P.M.; Wahlen, J.M. A Review of the Earnings Management Literature and Its Implications for Standard Setting. Account. Horiz. 1999, 13, 365-383. [CrossRef]

18. Schipper, K. Earnings management. Account. Horiz. 1989, 3, 91-102.

19. Roychowdhury, S. Earnings management through real activities manipulation. J. Account. Econ. 2006, 42, 335-370. [CrossRef]

20. Cohen, D.A.; Zarowin, P. Accrual-Based and Real Earnings Management Activities around Seasoned Equity Offerings. J. Account. Econ. 2008, 50, 2-19. [CrossRef]

21. Burgstahler, D.; Dichev, I. Earnings management to avoid earnings decreases and losses. J. Account. Econ. 1997, 24, 99-126. [CrossRef]

22. Bartov, E.; Givoly, D.; Hayn, C. The rewards to meeting or beating earnings expectations. J. Account. Econ. 2002, 33, 173-204. [CrossRef]

23. Lev, B. Corporate Earnings: Facts and Fiction. J. Econ. Perspect. 2003, 17, 27-50. [CrossRef]

24. White, G.I.; Sondhi, A.C.; Fried, D. The Analysis and Use of Financial Statements; Wiley: Hoboken, NJ, USA, 1994; ISBN 978-0-471-37594-4.

25. Bernard, V.L.; Stober, T.L. The nature and amount of information in cash flows and accruals. Account. Rev. 1989, 64, 624-652.

26. Jiambalvo, J.; Noreen, E.; Shevlin, T. Incremental Information Content of the Change in the Percent of Production Added to Inventory. Contemp. Account. Res. 1997, 14, 69-97. [CrossRef]

27. Gupta, M.; Pevzner, M.; Seethamraju, C. The Implications of Absorption Cost Accounting and Production Decisions for Future Firm Performance and Valuation. Contemp. Account. Res. 2010, 27, 889-922. [CrossRef]

28. Bernard, V.; Noel, J. Do Inventory Disclosures Predict Sales and Earnings? J. Account. Audit. Financ. 1991, 6, 145-181. [CrossRef]

29. Kim, B.H. The association between unexpected changes in inventories and abnormal returns: Cross-section analysis. Korean Account. Rev. 1993, 17, 195-227.

30. Ou, J.A. The information content of non-earnings accounting numbers as earnings predictors. J. Account. Res. 1990, 28, 144-163. [CrossRef]

31. Graham, J.R.; Harvey, C.R.; Rajgopal, S. The economic implications of corporate financial reporting. J. Account. Econ. 2005, 40, 3-73. [CrossRef]

32. Cohen, D.A.; Dey, A.; Lys, T.Z. Real and Accrual-Based Earnings Management in the Pre- and Post-Sarbanes-Oxley Periods. Account. Rev. 2008, 83, 757-787. [CrossRef]

33. Biggadike, R. The risky business of diversification. Harvard Bus. Rev. 1979, 57, 103-111.

34. Dess, G.G.; Davis, P.S. Porter's (1980) generic strategies as determinants of strategic group membership and organizational performance. Acad. Manag. J. 1984, 27, 467-488.

35. Singh, P.; Agarwal, N.C. The effects of firm strategy on the level and structure of executive compensation. Can. J. Admin. Sci. 2002, 19, 42-56. [CrossRef]

36. Hollander, M. A Distribution-Free Test for Parallelism. J. Am. Stat. Assoc. 1970, 65, 387-394. [CrossRef]

37. Ginsberg, A.; Venkatraman, N. Contingency Perspectives of Organizational Strategy: A Critical Review of the Empirical Research. Acad. Manag. Rev. 1985, 10, 421-434. [CrossRef]

38. Yuen, S.; Moores, K. Management accounting systems and organizational configuration: a life-cycle perspective. Account. Organ. Soc. 2001, 26, 351-389.

(C) 2019 by the authors. Licensee MDPI, Basel, Switzerland. This article is an open access article distributed under the terms and conditions of the Creative Commons Attribution (CC BY) license (http://creativecommons.org/licenses/by/4.0/). 